\title{
Industrial Service Engineering - Training Requirements for Systematic Service Development
}

\author{
Clemens Fischer*, Herbert-Michael Richter
}

\begin{abstract}
Increasing digitization and rising customer requirements represent an opportunity for companies in the machine- and plant engineering industry. For long-term success, combined packages of product and service must be offered, to gain additional revenues and a unique selling proposition. Basically, the advantages of these bundles are slowly establishing themselves in industrial companies. The problem is, that the development and improvement of these bundles run often unsystematically, without a strategy. In Austria, companies are facing the issue, that they are not able to develop new services, due to a shortage of specially skilled employees. This derives out of a lack of clear definition of educational requirements. In order to identify those gaps, an empirical investigation based on expert interviews was conducted and the current status of training requirements was defined. As a result, future service job profiles and potential trends for education and training in the service area of industrial companies were derived thus machine- and plant engineering companies can innovate their employee education strategy.
\end{abstract}

Keywords: digitalization; industrial services; new jobs; plant engineering industry; service engineering; training requirements

\section{INDUSTRIAL SERVICES}

In $2019,70 \%$ of the gross value added in Germany was generated in the service sector [1]. This illustrates the importance of services for society. Services can have many advantages for both companies and private consumers. Customers can receive individualised, adapted services and companies are, in turn, able to gain competitive advantage. Additionally, services can be provided in various manifestations. [2] In addition to traditional private and business services (e.g. cutting hair, security service, tax advisors), there are more and more services that have only emerged and continue to emerge as digitalization progresses (remote service, online training, internet banking) [3]. The interaction between providers and customers will be successively accelerated by the technologies used. The issue of digitisation (Industry 4.0) is also driving the development of services in manufacturing companies. Digital technologies make it possible to connect systems in a company more closely with each other [4]. In addition, services can also be more individualized, adapted to customer requirements and offered in a more flexible and resource-saving manner [5].

In manufacturing companies today, services are implemented as meaningful enhancements of business models with the intention to increase the turnover and profit of a company. The increased offer of services in the product and service portfolio of companies is due to the fact that companies are forced by increased competitive pressure to differentiate themselves from the competition. [6]. Industry 4.0 solutions and the associated hybrid products, in which services are supported and upgraded with machines, are expected to generate significant sales growth, averaging 13\% cumulatively over five years. The biggest challenges are, therefore, the high investments, the often still unclear economic efficiency calculation and the lack of standards and norms for industry 4.0 applications. However, expert companies also point to the insufficient qualification of employees [7].

\section{NEW SERVICES NEED NEW THINKING AND KNOWLEDGE}

The advancing digitalization changes the world in which we live and work in. Digitalization is revolutionizing entire industries, creating new business models and entering into all fields of professions [8]. The manufacturing industry is facing a fundamental change that affects both, its services and its production-/ work processes. New job profiles emerge that lead to changing demands on employees. Along with this, qualification requirements are also changing. Workers are expected to have all the skills necessary to adapt to technological change [9].

The development of digitization is also changing the old job profiles. Labour market experts assume that as the development progresses, above all, simple tasks will cease to exist. Konrad Wegener of ETH Zurich postulates that jobs for unskilled workers will cease to exist in Switzerland in the foreseeable future. In Germany, on the other hand, it is predicted that the loss of ancillary activities will be compensated by additional jobs created by digitisation [10].

According to a study by Ingenics and the Fraunhofer Institute for Industrial Engineering IAO, the requirements profile of production employees in particular will have to change. In the future, production will require people who, in addition to a high level of competence, also have the ability to act and think in an interdisciplinary manner. In addition, there are the skills required to understand complex processes and evaluate extensive data material [11]. The new requirements profile of people makes it necessary to adapt the contents of the training to the demands that arise from digitisation [12]. This means that forms of learning must be much more integrated into work processes and must be highly flexible and dynamically adaptable to changing requirements and different learning needs [13-15].

In this context, knowledge about new technologies has to be integrated into vocational and academic training [16]. Since the didactic possibilities seem almost unlimited, the question arises which teaching-learning methods and digital tools have to be selected to enrich existing and new learning opportunities. In this context, in addition to teaching content, 
the needs of the learners and the right choice of teachers are crucial [17].

In summary, it can be said that a stronger service orientation also places new demands on teaching staff [18].

The new requirement profiles for employees working in industrial services relate, for example, to IT skills and especially to data analysis, the results of which are increasingly providing the impetus for the development of new services $[19,20]$. In addition to the focus on technical knowledge, modern services also require non-technical skills such as project management or skills in dealing with customers. However, non-technical skills are not only considered important in the context of services, but for the overall rollout of all technologies associated with digitalization.

The literature is currently not very specific on industrial services. This is due to the fact that the developments in this area are still very new in the industry and in some cases have rarely established themselves in companies. There are some literature sources that provide procedures for the development of new industrial services, but they hardly deal with specific requirement profiles for employees [21-23]. If the focus is on employee development, it is usually in connection with change management, organizational development or the necessity of lifelong learning or general mission statements $[24,25]$.

On the basis of this initial situation, the study programme Industrial Management of the FH-Joanneum carried out a study in cooperation with entrepreneurs in Austria. The aim was to obtain an empirical result of the trends and requirement profiles of employees in the professional environment of industrial services. The Styrian Service Cluster (subsequently called SCC) was selected as a partner for this study as a consortium of 25 Styrian companies. This professional association of companies promotes the transfer of knowledge on service-related topics, as well as the exchange of best practice experience and strives to implement joint projects for innovative service solutions. In the following chapter, the methodology and the results of the study are explained in more detail.

\section{METHODOLOGY}

The methodology of the empirical survey is based on the method and procedure according to Dubé/Paré [26], which distinguish between the phases of research design, data collection and data analysis, shown in Fig. 1.

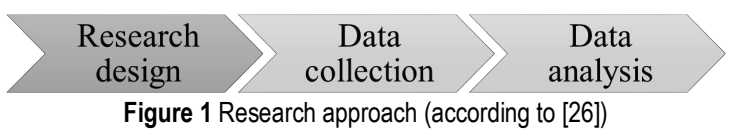

The procedure follows an iterative approach. Reflections and feedback loops are performed after each interview to further improve the interview process.

\subsection{Research Design}

The generation of requirement profiles for employees in the field of service engineering is a complex issue, so an active interpretation approach using qualitative research methods should be used [27]. Consequently, a comparative study based on expert interviews was carried out. Openended questions allowed the respondent to answer flexibly. This approach is likely to generate improved data quality [27]. In order to obtain a general statement, the comparative study uses a multi-case approach that includes several interviews on the same topic $[28,29]$. Since the interviews also dealt with methods and approaches for identifying new training priorities for employees, this empirical study also represents an explorative approach [26].

\subsection{Collection of Data}

The data was collected through interviews with experts of the companies within the SCC. These were semistructured interviews which, in contrast to standardised interviews, are open and adaptable to the respective situation. An interview guide was created in order to define a common theme, but also to create some degree of freedom regarding the questions and thier formulation.

\subsubsection{Selection of Respondents}

In order to be assumed to have the necessary experience and knowledge in relation to new services, the managers interviewed had to meet the following basic criteria:

- The respondent is an employee of a company that is a member of the SCC.

- The interviewee has responsibility in a service area.

- Service Engineering is already established in the organization of his company.

- The respondent's company already offers digitally supported services in addition to its main business.

From the 25 members of the SCC, 16 were identified by analysing the individual companies which were eligible for the survey based on their business models, customer structure and product characteristics. The response rate of this qualitative survey was $75 \%$ (12 of the 16 selected SCCmembers). The companies that were interviewed are active in sectors such as industrial waste re-processing (2), energy provider (1), (special) mechanical engineering (5), logistics (1), technology and electronics (1), industrial services (2). The companies surveyed were founded between 1712 and 1996, but on average they have existed for about 85 years.

\subsubsection{Interview Guide}

The interview guide represents the fundamental structure for the interview with the experts. As a collection of all questions to be raised during the interview, the guide must ensure that the interviews have the same common focus. On the other hand, it should not be too restrictive so that the statements are as open as possible [24].

In terms of content, the interview guide is divided into six main sections, each dealing with one of the major research topics: 
1. Questions on the integration of service offerings into the organization: Here, the importance of service in the company should be clarified.

2. Questions on the existing situation regarding service professions: the primary aim is to determine which activities and requirements are associated with service professions and which gap exists between the know-how currently available and the know-how deemed necessary from the point of view of the experts.

3. The third block of questions focuses on possible changes in business processes and on the future requirement profiles or further training requirements for service employees.

4. The fourth block of questions concerning personnel development in the company: Here the new and additional requirements and the future necessary number of employees and their training are enquired.

5. The fifth block of questions deals with whether the previously "non-existent" occupations are already advertised and whether companies in the vicinity have training facilities for these occupations.

6. Questions regarding necessary requirements: The prerequisites which must be fulfilled by employees working in industrial services in the future and which training contents must be the focus of training for industrial services were determined.

The Tab. 1 shows the questions that were used in the interview.

Table 1 Interview Questions

1. How is the service organization structured - centralized/decentralized?

2. How many employees work in the service department?

3. Current Service Professions

3.1 What activities and requirements go together with the mentioned professions (requirement profiles)?

3.2 Educational level of the employee (required minimum training)?

4. Future service occupations - Where is the journey going?

4.1 Which activities and requirements are associated with the abovementioned occupations (requirement profiles/further training requirements)?

4.2 For which of the above-mentioned requirement profiles do you think it could be difficult to find suitable personnel?

4.3 Educational level of the employee (minimum training required)?

5 . With regard to the additional/new requirements:

Will you need more/less or differently trained personnel in the future?

5.1 What strategy do you pursue with regard to changed/new requirements in the respective professions?

(further training of existing employees or acquisition of new employees)?

5.1.1 If you provide further training for existing employees, for which current service occupations in your company do you think further training/additional qualification is necessary?

Which activities are changing / are dropped / are added?

5.1.2 In your opinion, what is the maximum duration of further training required for the respective occupation? (until the respective activities can be carried out as desired?)

5.3 What is the maximum cost of the further training required for the respective profession?

6. Are "new" service jobs already advertised?

6.1 Do you have problems finding interested / qualified applicants?

6.2. If so, what problems arise? If no: What do you think is the reason why you do not have problems finding interested / qualified applicants?

7. Do you already have institutions in mind which offer these further training courses?
A test run was carried out to validate the interview guide before its application. Subsequently, the interview phase was conducted from 30 March 2018 to 27 April 2018. Each interview was conducted in German and by telephone. Each of the interview partners received the interview guide in advance. On average, an interview with the twelve selected interview partners lasted about 45 minutes.

\subsection{Data Analysis}

The data collected from the expert interviews were analysed in terms of content. According to Gläser/Laudel [29] the following four steps were carried out: in preparation, the recorded interviews were converted into an ordered and uniform text. During the subsequent extraction, information was taken from the written text and interpreted. In the next processing step, the extracted information is sorted according to the main topics, the content is aggregated and redundancies are removed. After the information was processed, the data was evaluated to answer the research question.

On the basis of the future requirements and activities specified by the interview partners for the respective service occupation, further training requirements were derived, stored in the survey matrix and then validated and approved by the respective expert.

\section{RESULTS}

The interviewed experts from the various companies provided very specific information on the new requirements that employees should bring with them into their jobs and on what should of special consideration when selecting employees. In addition, the results presented the currently prevailing challenges of training and further education of existing employees at the educational institutions known to the experts. After their elaboration, the results were presented to the SCC. The companies used them to create new strategies for employee development and new requirement profiles. The results thus also incorporated into the ongoing development of the Bachelor and Master degree programme in Industrial Management at FH JOANNEUM. This survey has thus reached the top companies in the manufacturing industry, which are intensively involved in new services. From the point of view of the experts surveyed, with the background that their companies are all internationally active, the results of the study can also be transferred to similar companies in other countries if they want to provide comparable services.

\subsection{Trends in Employee Requirements for Industrial Services}

The survey identified six main trends with regard to the demands of employees. The new service-oriented professions in the industrial sector require not only technical skills, but also further skills. On the one hand, in the area of rhetoric, intercultural communication and service-related language use. On the other hand, due to the increasingly 
digitalised technology of the systems and the services that have become possible as a result, an expanded level of knowledge is essential in the area of IT in addition to hardware know-how. Digital services can be used to support customers or plants all over the world. In order to follow the profitability calculations of the companies, these increasingly local subcontractors at the customer's premises are being used, which are trained by the manufacturer's trained technicians. To this end, tech companies offer communication solutions such as data glasses with video conferencing functions. As a result, the specialized service staff has to take over the leadership of the teams on site. This requires leadership and management skills and languages, at least English.

The exact trends and their corresponding aspects can be seen in Tab. 2. They were summarised from the experts' answers and prepared in text form below.

Table 2 Visualisation of trends

\begin{tabular}{|c|}
\hline Technical \\
Solid technical basic training is required \\
Social Skills \\
Rethoric \\
\hline Intercultural communication \\
\hline Service wording \\
Business knowledge \\
\hline Basics and wording of business administration/accounting/controlling \\
\hline Information Technology \\
\hline Understanding of syntax \\
\hline Data analytics \\
\hline Data scientist \\
\hline Language \\
\hline Fluent business English \\
\hline Second foreign language \\
\hline Leadership/General Management \\
Project management \\
\hline Quality management \\
\hline Negotiation training \\
\hline
\end{tabular}

\subsubsection{Technical}

One of the most important statements regarding current or future service occupations was, that people with a solid technical education, such as a degree from a higher technical college or an industrial engineering degree, are preferred. In the service sector, companies consider technology to be the most important area, which is why the technical foundation should already be in place before a potential new employee joins the company or after completing an apprenticeship. The companies demand know-how in areas such as mechanics, mechanical engineering, electronics and electrical engineering. It is not uncommon for basic knowledge of information technology to be required.

\subsubsection{Social Skills}

All of the responsible persons interviewed stated, either at their own initiative or upon request, that social interaction is very important, especially for employees that are in contact with customers. In general, several focal points can be derived from this. Companies want employees who are well versed in rhetoric and can argument aspects well and objectively. Furthermore, knowledge on topics such as claim management, conflict management and intercultural communication was also mentioned. How do I behave in conflict situations? How do I avoid conflicts at all? What does it mean to possess social competence? All the aspects that employees should be given in the course of training. It should not remain unmentioned that some companies also attach great importance to presentation techniques. This should therefore also be taught in the course of training.

\subsubsection{Knowledge of Business Administration}

Business management knowledge is essential, especially for technicians who have a management position in the company. Above all, knowledge of accounting (reading or interpreting a balance sheet and profit and loss account) and controlling (cost accounting) is required. Nearly all of the interviewed entrepreneurs were also convinced that it is much easier to explain the basics of business administration to a technician than it is to impart technical knowledge to a business economist.

\subsubsection{Information Technologies}

Nearly all of the companies surveyed are of the opinion that IT skills will be increasingly required of employees in almost all service professions in the future. In addition, due to the process character of the technical procedures in which the service technicians work, an ever deeper understanding of the interrelationships of the digitalized industry is required.

\subsubsection{Languages}

Another important aspect from the point of view of the service managers surveyed, is the level of proficiency in foreign languages. In Austria English is considered a basic requirement (spoken and written) in most companies. A significant number of companies are also of the opinion that mastering a second living foreign language will be relevant in the future. This means an additional to German and English language, for example, French, Spanish or Russian. This is particularly important in view of the increasing globalisation in various industries. The choice of language depends on the company and its partners or customers and varies from industry to industry.

\subsubsection{Leadership}

It is not without reason that the topic of leadership was excluded from the social skills trend. The background is that several companies stated that not every employee will automatically hold a leadership position in the future. However, with regard to the training of managers, the companies surveyed would like to see

- a general improvement in leadership behaviour,

- training in the field of conflict management,

- training/knowledge in the field of intercultural communication, 
- $\quad$ negotiation training

- $\quad$ training to improve self-presentation

- $\quad$ and knowledge of project management.

\subsection{Problems Mentioned by the Interview Partners}

The experts specified the various requirements that will be demanded from employees in the future due to the changed product range for industrial plants. In addition, they also expressed their views on the challenges that are also connected to the training and further education and the image of services. On the one hand, this concerns the duration of additional training and the corresponding regulations of the training institutions, such as compulsory attendance. On the other hand, the association of the word "service" is often still strongly anchored in the gastronomic sector or is associated with dirty work in the industrial sector.

\subsubsection{Duration of Training or Access Regulations}

Almost all companies complained about a central problem, namely that most of the training courses they were aiming to offer, were not accessible to a large group of people. This is, on the one hand, due to the fact that companies on average do not want to exceed a training period of one to a maximum of two years, and on the other hand to the fact that employees who do not have an intermediate school leaving certificate (apprenticeship training/master school) are refused interesting training opportunities. In concrete terms, this means that an excellent technician with enormous know-how cannot get the necessary teaching content, as this is handled in a master's degree course. This is where companies would like to rethink the access regulations of the universities.

\subsubsection{Compulsory Attendance at Teaching Institutes}

The compulsory attendance obligations imposed on employees who complete their training on a part-time basis represent a major challenge for companies. Particularly with regard to service technicians who work in the field, attendance obligations represent a major hurdle. On the one hand, service technicians often cannot be sent on longer trips and, on the other hand, they cannot travel over the weekend because of training courses on Saturdays. For this reason, at least in the opinion of many of the companies surveyed, there should be a larger number of e-learning units. This would be a logical consequence of increasing globalisation and rapidly advancing digitalisation. Employees would be able to better plan their work and at the same time, they could attend lectures, trainings or courses from almost anywhere in the world.

\subsubsection{Image of "Service" and Recruiting of Suitable Candidates}

One topic that was mentioned by almost all the companies surveyed is the poor service image. The companies are of the opinion that the service sector is negatively affected, mainly because of most people associate service either only with the catering industry or alternatively with a hammer, wrench and dirt (as formerly mentioned in 4.2). This, in turn, means that job advertisements hardly succeed in attracting qualified and well-trained potential employees. No matter how well the job itself is described or circumscribed, applicants do not even look for vacancies in the service sector on various application portals. If many of the interviewees are of the opinion that this is the case, then academically trained people, in particular, are not aware of the exciting and at the same time challenging professions and activities the service sector has to offer. It is not without reason that the SCC already tried several years ago to find out what people living in Austria associate with service by means of interviews with passers-by in a pedestrian zone. The interviewed companies were or are in agreement that the image of the service sector needs to be improved.

A major result of this survey was also that many companies mentioned a relatively young profession, the data scientist. This is an expert in the field of data analysis and has the task of utilizing the constantly growing amount of data (in operation, for example through condition monitoring systems or predictive maintenance) in the company. With predictive maintenance, a correct interpretation of large amounts of data can give a significant competitive advantage over competitors who continue to maintain reactive service.

\section{CONCLUSIONS}

The creation and implementation of industrial services pose completely new challenges for companies in the manufacturing industry and their employees. Many people do not yet know where the journey of the new industrial (r)evolution and the possible accompanying change of business models will ultimately lead to, but companies can begin to prepare their employees for this change. Important points here are a better information policy and consistent training and further education in all areas.

One of the most important aspects of the training and further education of employees in the industrial services sector is the recognition of trends in the skills required by the services and expected by the customers. To summarize the trends that have been identified, it should be noted that companies need well-trained all-rounders, who combine knowledge and skills that have previously been divided among many people.

To this end, however, the development of transparent processes within the company must also be promoted so that closer cooperation between different departments does not fail due to a lack of understanding. In addition, the motivation of employees must be strengthened and the fear of change reduced. This includes involving employees from all departments more closely in internal information processes. In-house and external further training promoted by the company is also proving its worth in order to positively prepare employees for the new challenges. In order to make the image of the service profession more attractive, a joint marketing campaign by the companies must be promoted. 
This also includes the possibility of completing the necessary training courses virtually, which has so far only been done selectively. The current Covid19 situation, in which teaching is exclusively virtual, can provide an impetus for educational institutions such as colleges and universities to expand their e-learning offerings for the benefit of companies and in view of the need for well-trained employees.

Basically, not only the companies in the industry are at the beginning of a change in the new skills required from employees and managers, but also the applied research in many fields is facing a new challenge. New technologies make new hybrid products possible, but also require new methods to impart the necessary knowledge. This is where training institutions are called upon to find a practicable solution in close cooperation with the industry.

The study determines necessary service-related skills, beyond the technical/technological capabilities of the employees. Further studies of the Institute of Industrial Management will address the necessary service-related skills related to the new digital technologies which were not the subject of this study. Equaly, obstacles to the training of working professionals with secondary education (without a bachelor's degree) will also need to be surveyed, as companies and their employees do not only have access to M.Sc. level training.

\section{Notice}

The paper will be presented at MOTSP 2020 International Conference Management of Technology - Step to Sustainable Production, which will take place from $30^{\text {th }}$ September $-2^{\text {nd }}$ October 2020 in Bol, island Brač (Croatia). The paper will not be published anywhere else.

\section{REFERENCES}

[1] Statistisches Bundesamt (2019). Statistisches Jahrbuch 2019, Retreived from: https:/www.destatis.de/DE/Themen/ Querschnitt/Jahrbuch/statistisches-jahrbuch-2019dl.pdf? blob=publicationFile (2020).

[2] Leimeister, J. M. (2020). Dienstleistungsengineering und management. Berlin: Springer. https://doi.org/10.1007/978-3-662-59858-0

[3] Engels, G., Plass, C., \& Ramming, F.-J. (2018). IT-Plattformen für die Smarte Service Welt, Retreived from: https://www.acatech.de/wp-content/uploads/2018/03/ITPlattformen_DISKUSSION_WEB.pdf (2020).

[4] Abramovici, M. (2018). Engineering smarter Produkte und Services Plattform Industrie 4.0 STUDIE. Retreived from: https://www.plattform-

i40.de/I40/Redaktion/DE/Downloads/Publikation/hm-2018fb-smart.pdf?_blob=publicationFile \&v=3 (2020).

[5] Schüritz, R., Seebacher, S., Satzger, G., \& Schwarz, L. (2017). Datatization as the Next Frontier of Servitization. In: Proceedings of the International Conference on Information Systems (ICIS). Seoul, Südkorea.

[6] Wonner, R. (2016). Determinanten des Bedarfs an produktbegleitenden Dienstleistungen auf Industriegütermärkten. Ingolstadt: Katholische Universität Eichstätt-Ingolstadt.
[7] PwC Österreich GmbH (2015). Industrie 4.0 - Österreichs Industrie im Wandel. Retreived from: http://www.pwc.at/herausforderung/digitaletransformation/industrie-4-0-studie.html (2020).

[8] Heim, Y., Petzoldt, A., \& Bullinger-Hoffmann, A. C. (2016). Die Arbeitswelt der Zukunft. Wirtschaftsmagazin SACHSEN, 2016/2017.

[9] Poschmann, K. (2015). Berufliche Weiterbildung im Zeitalter der Digitalisierung. DIW Roundup: Politik im Fokus, 84. Retreived from: www.diw.de/documents/publikationen/73/ diw_01.c.519856.de/diw_roundup_84_de.pdf (2020).

[10] Inside Business (2019). Industrie 4.0: Welche neuen Aufgaben erwarten die Mitarbeiter? Retreived from: https://www.wlw.de/de/inside-business/aktuelles/industrie-40 -jobs (2020).

[11] Ingenics/Fraunhofer IAO (2014). Industrie 4.0 - Eine Revolution der Arbeitsgestaltung. Retreived from: https://blog.iao.fraunhofer.de/industrie-4-0-eine-revolutionder-arbeitsgestaltung/ (2020).

[12] Lichtblau, K., Stich, V., \& Bertenrath, R. (2015). Industrie 4.0 Readiness. Impuls-Stiftung des VDMA, Aachen/Köln. Retreived from: http://www.impuls-stiftung.de/studien; jsessionid=3E8E28426AF66D-3D6AC6D0F93BFFB22C (2020).

[13] Kuhlmann, A. \& Sauter, W. (2008). Innovative Lernsysteme. Kompetenzentwicklung mit Blended Learning und Social Software. Berlin/Heidelberg: Springer.

[14] Hofert, S. (2016). Agiler führen. Einfache Maßnahmen für bessere Teamarbeit, mehr Leistung und höhere Kreativität. Heidelberg: Springer. https://doi.org/10.1007/978-3-658-12757-2

[15] Melzer, A. \& Bullinger, A. C. (2017). Erfolgsfaktor Skalierbarkeit. Digitales Kompetenzmanagement, das mitwächst. HMD, 54(6), 977-992. https://doi.org/10.1365/s40702-017-0373-7

[16] Feldhoff, A., Zeiner-Fink, S., Heim, Y., \& Bullinger, A. C. (2019). So will ich lernen! Nutzeranforderungen an die Qualifizierung für Arbeit 4.0. Wiesbaden: Springer. https://doi.org/10.1365/s40702-019-00550-5

[17] Tulodziecki, G., Herzig, B., \& Blömeke, S. (2017). Gestaltung von Unterricht: Eine Einführung in die Didaktik. Stuttgart: UTB.

[18] Dachs, B. \& Simon, N. (2016). Dienstleistungsinnovationen im Kontext von Industrie 4.0, AIT-IS Report. Retreived from: https://www.ffg.at/sites/default/files/dienstleistungsinnovation en_im_kontext_von_industrie_4.0.pdf (2020).

[19] Haydecker, J. (2014). Neue Anforderung an Mitarbeiter und Unternehmen durch Industrie 4.0, Crisp Research. Retreived from: https://www.crisp-research.com/neue-anforderungmitarbeiter-und-unternehmen-durch-industrie-4-0/ (2020).

[20] Büst, R. (2014). Der Einfluss des Internet of Things auf den CIO, Crisp Research. Retreived from: https://www.crispresearch.com/der-einfluss-des-internet-auf-den-cio/? clouduser=true (2020).

[21] Leimeister, J. M. (2012). Dienstleistungsengineering und management, Berlin Heidelberg: Springer Gabler. https://doi.org/10.1007/978-3-642-27983-6

[22] Bullinger, H.-J. \& Scheer, A.-W. (2003). Service Engineering: Entwicklung und Gestaltung innovativer Dienstleistungen, Berlin Heidelberg: Springer Gabler. https://doi.org/10.1007/978-3-662-09871-4_1

[23] Leimeister, J. M. (2020). Dienstleistungsengineering und management - Data-driven Service Innovation, $2^{\text {nd }}$ Ed., Berlin Heidelberg: Springer Gabler. https://doi.org/10.1007/978-3-662-59858-0 
[24] Ganz, W. \& Bienzeisler, B. (2010). Mangement hybrider Wertschöpfung, Stuttgard: Fraunhofer Verlag.

[25] Breit, H., Bullinger-Hoffmann, A. C., \& Canter, U. (2017). Produktivität von industriellen Dienstleistungen, Wiesbaden: Springer Gabler. https://doi.org/10.1007/978-3-658-08632-9

[26] Dubé, L. \& Paré, G. (2003). Rigor in Information Systems Positivist Case Research: Current Practices, Trends, and Recommendations. MIS Quarterly, 27(4), 597-636. https://doi.org/10.2307/30036550

[27] Schreier, M. (2012). Qualitative content analysis in practice, London: Sage.

[28] Flick, U. (2009). An introduction to qualitative research, 4. Ed., Los Angeles: Sage Publications.

[29] Yin, R. K. (2009). Case study research: Design and methods, 4. Ed., Los Angeles: Sage Publications.

[28] Helfferich, C. (2011). Interviewplanung und Intervieworganisation, in: Helfferich, C. (Hrsg.): Die Qualität qualitativer Daten, Wiesbaden: VS Verlag für Sozialwissenschaften, 2011, 167-193. https://doi.org/10.1007/978-3-531-92076-4_6

[29] Gläser, J. \& Laudel, G. (2010). Experteninterviews und qualitative Inhaltsanalyse: Als Instrumente rekonstruierender Untersuchungen, 4. Ed. Wiesbaden: VS Verlag für Sozialwissenschaften. https://doi.org/10.1007/978-3-531-91538-8

\section{Authors' contacts:}

Clemens Fischer, MSc. in Eng Industrial Mangement, FH JOANNEUM,

Werk-VI-Straße 46, Kapfenberg, A-8605, Austria

+43316 5453-6353, Clemens.Fischer@fh-joanneum.at

Herbert Michael Richter, PhD, MSc. in Eng

Industrial Mangement, FH JOANNEUM,

Werk-VI-Straße 46, Kapfenberg, A-8605, Austria

+43 316 5453-8326, HerbertMichael.Richter@fh-joanneum.at 